INSIGHTS INTO REGIONAL DEVELOPMENT

ISSN 2669-0195 (online) http://jssidoi.org/IRD/ 2020 Volume 2 Number 3 (September)

http://doi.org/10.9770/IRD.2020.2.3(5)

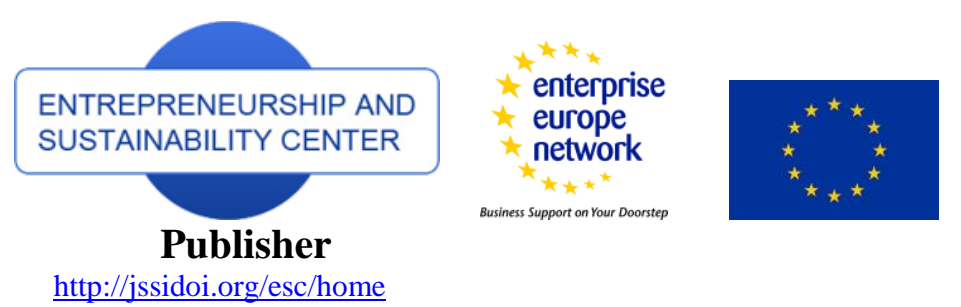

\title{
THE SIGNIFICANCE OF STRATEGIC MANAGEMENT ACCOUNTING ON THE PERFORMANCE OF TRANSPORT BUSINESSES IN NIGERIA
}

\author{
Adetayo Olaniyi Adeniran ${ }^{1}$, Oluwabukunmi Eunice Obembe ${ }^{2}$ \\ ${ }^{I}$ Department of Transport Management Technology, of the Federal University of Technology Akure, Nigeria \\ ${ }^{2}$ Department of Accounting, of the National Open University of Nigeria \\ E-mails: ${ }^{1}$ adeniranao@futa.edu.ng , ${ }^{2}$ oobembe97@gmail.com
}

Received 15 March 2020; accepted 20 July 2020; published 30 September 2020

\begin{abstract}
The study provided that strategic management accounting is related to the provisions and use of accounting information by people in the organization such as the management and the managers, to make business decisions that would enhance competitive advantage and effective control of the firm's activity. The major purpose of this study is to investigate the significance of the strategic role of strategic management accounting in realizing the better performance of transport businesses in Nigeria. The study generated data from 230 transport businesses in Nigeria through a cross-sectional questionnaire survey approach using drop and pick means of data distribution. The findings revealed that factors such as information, people, and government policy are significant factors impacting the performance of the transport business. Hence, it was suggested that the factors are essential in realizing the performance of transport businesses. Also, the findings reveal that technology has a significant effect on the performance of transport businesses, and revealed the relationship between strategic management accounting and business performance. It is pertinent to note that this study would be of advantage to all transport business owners and researchers as it would give a plausible guideline for taking vibrant decisions concerning business performance, and will be a basis for future research. Based on the findings, it is therefore concluded that information, people, government policy, and technology are the significant factors necessary to induce the efficient performance of the transport business in Nigeria.
\end{abstract}

Keywords: Strategic management accounting, Transport business, performance, Nigeria

Reference to this paper should be made as follows: Adeniran, A.O., Obembe, O.E. 2020. The significance of strategic management accounting on the performance of transport businesses in Nigeria. Insights into Regional Development, 2(3), 677-688. https://doi.org/10.9770/IRD.2020.2.3(5)

JEL Classifications: R4, R5

\section{Introduction}

Commonly, the strategic management accounting concept is not new in most fields like accounting, marketing management, business management, etc. Hence, it has come across many fields of human endeavor. Strategic management accounting is considered both financial and non-financial in dynamic and it is often used for the purpose such as making decisions, execution of decisions and controlling decisions to ensure it does not go beyond the boundary of such decision. The accounting section or department, in particular, is saddled with the 


\section{INSIGHTS INTO REGIONAL DEVELOPMENT}

ISSN 2669-0195 (online) http://jssidoi.org/IRD/

2020 Volume 2 Number 3 (September)

http://doi.org/10.9770/IRD.2020.2.3(5)

responsibility of providing management accounting information that is necessary and required by the management.

Strategic management accounting according to France (2006); Uyar (2010) is the provision and usage of accounting information by people in the organization such as the management and the managers, to make business decisions that would enhance competitive advantage and effectively control the firm's performances. Strategic management accounting is quite dominant in large firms. However, lately, the popularity has been extended to enterprises. In other words, the role of strategic management accounting cannot be underestimated (Uyar, 2010; Senan, 2018; Vegera et al., 2018; Wakuła, 2020).

It stands as a foundation for making business decisions that would improve or positively affect the performance of firms. It helps firms to have a better competitive advantage over competitors.

Nonetheless, one major issue confronting business enterprises across the globe is the inappropriate financial management resulting from the lack of strategic management accounting practices (Shehab, 2008). Okpara et al. (2007) pointed out that the lack of financial management has contributed to business failures. The case of enterprises in Nigeria is no different as many of them are lacking proper financial planning and decision-making. No doubt, good financial planning, and decision making are indispensable for the enterprise's performance particularly in these present days where competition seems to be very high among the enterprise (Shehab, 2008).

To address this problem requires firms to practice a strategic management accounting system as suggested by Sheheb (2008). This study is set to examine the significance of strategic management accounting on enterprise performance in Nigeria. In today's competitive environment, enterprises must seek and rely on correct information. This information should be used to analyze and predict future decisions that would affect firm performance. Therefore, the enterprise should be concerned with what the rate of return on the money is, whether to buy one piece of equipment or another and which one would generate better profit but not necessarily which one will work best on an operational basis, and how to maximize profits from future decisions. Thus, achieving this requires the role of strategic management accounting in ensuring that decisions concerning the performance of the firm are duly met.

Nigeria is a country that has experienced a different form of devastation such as terror acts, violence, corruption, political instability, and decentralized practices which may have negative implications on the economy. Enterprises, which are the root of a country's economy, have made little progress and this is due to lack of smooth flow of goods and services to fulfill the functions of regional complementarity, intervening opportunities and spatial transferability, and high start-up costs and limited government funding, and inaccurate financial information from the enterprise owners.

Critical observation would indicate that many business firms have always focused on the traditional financial accounting information in making decisions concerning product quality, operational efficiency, cost reduction, and others and this has proven very difficult and sometimes, badly affected the management decisions. Thus, the traditional financial accounting information could not do much for the management in affecting enterprise decisions that could improve firm performance. This is because the information provided by traditional financial accounting seems very unsystematic and has limited functions (Norma and Paolo 2010).

Despite the actions of the government to resuscitate the enterprises, there seems to be a slight uplift. On this note, the significance of strategic management accounting becomes very crucial to aid the enterprise to improve its performance. Therefore, business enterprises must look for an alternative approach that would help them to improve their decision making, cost efficiency, and operational efficiency and in turn, improve their performance. 


\section{INSIGHTS INTO REGIONAL DEVELOPMENT}

ISSN 2669-0195 (online) http://jssidoi.org/IRD/

2020 Volume 2 Number 3 (September)

http://doi.org/10.9770/IRD.2020.2.3(5)

To achieve this, the firm must re-evaluate its management practice of decision making and one of the ways of getting this information is through a strategic management accounting system.

Because strategic management accounting involves a well and systematically planned system of data collection, processing, storage and dissemination of data and execution of the data by the management for decision making and performance improvement, it is, therefore, crucial that the role of strategic management accounting in firms should be investigated. On this premise, this study examines the significance of strategic management accounting on the performance of the transport business in Nigeria.

The objectives of this study are to:

i. investigate the relationship between strategic management accounting and the performance of the transport business in Nigeria;

ii. determine the strategic role of strategic management accounting in enhancing transport business performance; and

iii. explore the factors affecting the performances of transport businesses in Nigeria.

\section{Literature Review}

\subsection{Strategy and management accounting}

The concept of strategy is quite ambiguous and it has several definitions. To start with, the concept of strategy could be divided into a corporate, business unit, and functional strategies. Strategy research could be broadly divided into three phases: the classical strategy and structure research, analytic strategy research including socalled generic strategies, and more recent subjectivist oriented and process-oriented research (Quinn, James and Mintzberg 1988). Cooper (1996) introduced such concepts as survival zone, confrontation strategy, and simultaneous importance of product functionality, quality, and price under intensive competition. Miles and Snow (1978) categorized different strategic types such as defenders, prospectors, analyzers, and reactors. Based on this, the firms respond to environmental factors that in one way or the other configure technology, organizational structure, and processes to achieve the firms' strategic objectives.

The first two categories of strategic management orientation and thought treated strategy as quite an unproblematic field. Strategies are believed to be formulated in linear, rational, systematic, and analytical ways and they are seen as proactive and formal plans for achieving firm objectives in ensuring its survival (Dent 1990). However, Lindblom (1959) saw strategies surviving somehow by "muddling through" of incremental and unrelated decisions and actions. Mintzberg et al. (1976) argued that decision making was continuously interrupted, continued, and repeated, thus precluding any element of consistency. Expressing a similar position, Pettigrew (1985) averred that the strategic decision making constituted conflicts and fights between different coalitions or segments within an organization. These organizationally grounded researches see strategic decisions as a messy, disorderly, and disjointed activity with conflicting interests. According to the incremental strategy perspective, strategic management is not linear and rational action but strategies are formulated or emerged through social processes, and the emphasis is thus in the process view and the role of actors in this process can be seen as increasing (Pettigrew, 1985).

According to Quinn (1980), incrementalism in strategic management formulation did not arise via muddling through, but it is a purposeful, conscious, effective, and systematic executive practice based on iterative series where strategies are generated and implemented incrementally. The interpretative strategy perspective assumes that reality is socially constructed and it holds that the complexity of strategic management is due to the attitudinal and cognitive complexity among diverse stakeholders (Johnson 1987, Santala 1996). Thus, it is argued that managers shape the minds and attitudes of the organization's members in a way that is expected to produce 


\section{INSIGHTS INTO REGIONAL DEVELOPMENT}

ISSN 2669-0195 (online) http://jssidoi.org/IRD/

2020 Volume 2 Number 3 (September)

http://doi.org/10.9770/IRD.2020.2.3(5)

favorable results (Chaffee 1985, Pettigrew 1985, Santala 1996), while strategy is a mental image, an abstraction, which exists only in minds. In essence, strategic management is a tool to manage an organization's culture while motivation and commitment are essential success factors and the scope of the strategic management is not just on top management, but it is an organization-wide issue.

According to Quinn (1980), incrementalism in strategic management formulation did not arise via muddling through, but it is a purposeful, conscious, effective, and systematic executive practice based on iterative series where strategies are generated and implemented incrementally. The interpretative strategy perspective assumes that reality is socially constructed and it holds that the complexity of strategic management is due to the attitudinal and cognitive complexity among diverse stakeholders (Johnson 1987, Santala 1996). Thus, it is argued that managers shape the minds and attitudes of the organization's members in a way that is expected to produce favorable results (Chaffee 1985, Pettigrew 1985, Santala 1996), while strategy is a mental image, an abstraction, which exists only in minds. In essence, strategic management is a tool to manage an organization's culture while motivation and commitment are essential success factors and the scope of the strategic management is not just on top management, but it is an organization-wide issue.

\subsection{Development of strategic management accounting}

The management and practice of accounting have witnessed a significant transformation. Roslender and Hart (2002) note that it has been the site for a growing array of developments designed to restore the relevance of accounting to management. One of the most noted vanguards in the re-invention of management accounting practices in contemporary time was Kaplan. Kaplan's contribution to the re-invention of management accounting practices in the 1980s involves the promotion of Activity-Based Costing. As Otley (2001) notes, Activity-Based Costing has given rise to the prominence of other management accounting sub-issues- the most important being Activity-Based Budgeting, Activity-Based Cost Management, and Activity-Based Management. Otley (2001) contends that perhaps it is in the cost management process itself that the biggest adaption in management accounting practices has taken place. Thus, Kaplan's work can be seen as part of a more general movement to adapt and change the management accounting practice. Arguably, one of the most noted outcomes of the process of adaption and change that the work of Kaplan gave rise to in the process of management accounting practice was the emergence of strategic management accounting as a new form of management accounting practices and processes.

Technology

ECA (2001) notes that to foster the economic performance and competitiveness of enterprises, functional, highquality basic infrastructure is required. An optimal physical and information technology infrastructure includes a good, well-maintained road network, functional airport, and seaport, a stable power supply, and an extensive telecommunication network. Othman (2005) affirmed that technology infrastructure impact in a significant manner on rural development as it has the potential to stimulate the establishment of new enterprise and buoyed the growth of previously existing ones. Technology which deals with modern computer application and software assist the enterprise in the processing of information for effective and efficient organizational management. However, this is contingent on the optimal provision of other infrastructural facilities notably stable power supply. Arowomole (2000) noted that the impact of technology on the enterprises is overwhelming as it facilitates speedy making and communication of management decisions within firms and to other establishments.

\section{Information}

The present globalization of business has compelled many firms including Enterprise to seek and rely on the information. This information is used to analyze and predict future decisions that would affect the enterprise 
performance. Soleman (2008) noted that the information system which is part of the information could affect the organization. Therefore, the enterprise must concern them with accurate information that would translate to enterprise performance.

\section{People}

The Economic Commission for Africa in a report on enhancing enterprise performance notes that it is widely acknowledged that the development of a country's industrial and entrepreneur capabilities requires investment in human capital (ECA, 2001). ECA (2001) notes that with the increasing pace of technological change, the spread of information technologies, and intensifying competitive pressures, the need for specific skills have become even more demanding. People imbued with skills in technologies and entrepreneurship is not just employees, they constitute the heart and driving force of any business whether small or large.

\section{Government policy}

Government actions and policy decisions play significant roles in determining firm performance and the level of their contribution to national economic growth and development. Malhotra, et.al (2006) note that over the past two decades, the enterprise has become targets of policies aimed at promoting economic growth and employment in developing countries. This was mainly in recognition of the roles that enterprise play in development. Governments and donor agencies have advocated paying special attention to enterprise given their particular contribution to poverty reduction, employment generation, and private sector development. However, Malhotra et.al (2006) note that despite this growing interest, the debate on enterprise remains controversial within the development community, especially in light of the poor results of traditional pro-enterprise government policies especially in developing and transitional economies. In particular, the conceptualization of enterprise assistance in terms of welfare and social protection rather than firm efficiency and sustainability has led to overly protectionist policies that have hindered the development of the private sector.

\subsection{Small and Medium Enterprises (SMEs)}

Small and medium-sized enterprise is said to be the most important sector of a nation's economy based on their perceived and actual contribution to economic growth and national development. Ruth (2000) notes that business enterprise provides and create jobs; especially during the time of economic recession; they are a source of business innovation and entrepreneurial spirit; they harness individual creative effort, and they create competition and are the seedbed for businesses of the future. It is in recognition of their importance, that one can appreciate Hill (2001) positions that enterprise plays an increasingly important role in many economies. Ruth (2000) also acknowledges that small and medium-sized firms are of vital importance for a healthy and dynamic market economy.

According to OECD (2004), the establishment and nurturing of enterprise is a vital ingredient in creating dynamic market economies in the economic and social development of transition and developing countries. Entrepreneurs are the big drivers of economic growth, innovation, regional development, and job creation. A strong and vibrant enterprise sector provides a strong foundation to increase standards of living and to reduce poverty. Small and Medium-sized Enterprises have become one of the best means of economic growth. They also suit emerging economies as proven by the large success of various types of companies. The growth of a healthy, competitive enterprises sector will be maximized when there is a strong enterprise culture in the society at all levels; continuous growth in the quality stock of independent business; maximum potential for growth of existing small businesses: and a highly supportive economic, social and stakeholder environment. 


\section{Firms'performance}

Murphy, Trailer, and Hill, (1996) argued that accurate performance measurement is critical to understanding small businesses' success and/or their failure. Also, Trkman (2009) noted that performance measure is indispensable for small firms because it helps them to ascertain the success or failure of the firm and also acts as an indicator to achieve sustainable improvement in entrepreneurial and business activities. This implies that the issue of performance in the discussion of small firms cannot be ruled out since their success and/or failure is hinged on performance measurement.

According to Neely et al. (1995), the measurement could be viewed as the process of quantification and by which action is assessed against the outcome seen as a performance. However, there are two major methods by which measurement can be achieved. They include the objective and subjective methods of performance measurement. According to Simons (2000) objectives methods mostly measure independently and also verified independently. On the other hand, subjective measures are based on subjective evaluation. Thus, it can be argued that subjective measure provides data for determining the worth of the evaluation.

\section{Methodology}

In this study, a cross-sectional research design which is also referred to as social design is adopted. This research design is often used by the social scientists or social science field in carrying their research work (Neil, 2009). It mainly concentrates on collecting data on a single point not only that but also at a particular time, unlike the longitudinal design which has to collect data in various periods and different points. The research design of this study will assist to establish the relationship between the dependent variable and independent variables.

From the study of Shehab (2008), the unit of analysis of this study is an organization that is, transport business owners and the accountants, in line with the aim of this study which is to determine the significance of strategic management accounting in realizing business performance.

According to Shehab (2008), these individuals are the most suitable to provide information about the dimensions of this study. The population of this study comprises the transport businesses in Nigeria which is unknown. The use of the sampling size determination formula of Zikmund was applied at a random error allowance of 0.05 was applied to realize 384. According to Zikmund (2003), the various error allowances were determined and the suitable one was chosen based on the discretion of the researcher. The chosen error allowance of 0.05 was employed to establish the sample size as shown in the equation below:

The formulae for achieving sample size $\mathrm{n}=\frac{\mathrm{z}^{2}}{4 \mathrm{E}^{2}}$

where;

$\mathrm{n}=$ sample size;

$\mathrm{Z}=\mathrm{Z}$ score for the confidence interval (1.96);

$\mathrm{E}=$ Error allowance $(0.05)$

When inserted into the formula, Sample Size was 384. It is therefore crucial that the questionnaire distribution will target three hundred and eighty-four respondents who are owners, middle and top managers and accountants in the transport businesses.

Information was obtained via the face-to-face questionnaire and telephone/WhatsApp questionnaire administration to transport businesses, specifically, owners and the accountants. Hence, the actual sample of the study is 230 giving a response rate of 59.9 percent. 


\section{Results and Discussions}

To ensure that that data collected from the field survey was devoid of wrong data; the researcher first, screened the data. One of the major reasons for screening the data is to detect the error if any, in particular those data which are out of range. Julie (2007) suggests that data screening is necessary to ensure that data is error-free. Conversely, there was no data error or out of range reported in this study. On this note, data analysis can be conducted.

From the descriptive analysis conducted, out of 230 respondents that participated in the survey, 45.22 percent are managing directors, 54.78 percent are managers, or operating officers or employees. Furthermore, all the businesses surveyed are private companies. To determine the nature of the transport business, the following are surveyed: 9.57 percent are into warehousing, 24.35 percent are into spare parts dealing, 31.3 percent are into tyre dealing, and vulcanizing, 15.65 percent are into vehicle maintenance and repairs, and 19.13 percent are bus operators. Out of 230 transport businesses that took part in the study, 55.7 percent of them apply computerized strategic management accounting method while 44.3 percent applies the manual method of strategic management accounting

In this study, a multiple linear regression analysis was carried out to establish the relationship between the dependent variable and independent variables. This was employed to examine the dynamic relationship between the dependent (performance of transport business) variable and the independent (Strategic management accounting, technology, information, people, and government policy) variables under study.

\section{Regression Analysis Result}

Generally, there are five steps involved in hypothesis testing. In the study of Adeniran (2018), they are;

a. State the assumptions. The assumptions are:

Null Hypothesis $\mathrm{H}_{0}$ (there is no significant relationship between the dependent variable(s) and the independent variable(s). Also, Alternate Hypothesis $\mathrm{H}_{1}$ or $\mathrm{H}_{\mathrm{a}}$ (there is a significant relationship between the Dependent variable(s) and the independent variable(s).

b. Determine the table value from the Degree of Freedom and the already set critical region or significance level (0.05, or 0.01, or 0.025). There are different Degrees of Freedom for each test; it depends on the type of test being carried out (parametric or non-parametric test).

c. Calculate or compute the test statistics using either the parametric test or the non-parametric test.

d. State the decision rule. The decision rule for the calculated test states that if the calculated value of the test statistics is more or greater than the table value, the Null Hypothesis will be rejected, but if the calculated value of the test statistics is less than the table value, the Null Hypothesis cannot be rejected. The decision rule for the computed test states that if the significance level of the computed test statistics (p-value) is less than the chosen critical region commonly 0.05, the Null Hypothesis will be rejected, but if the significance level of the computed test statistics (P. Value) is more than the chosen critical region commonly 0.05 , the Null Hypothesis cannot be rejected.

e. The calculated value will be compared with the table value, or the significance level of the computed test (P.Value) will be compared with the chosen critical region, and the decision rule either to reject or not reject the Null Hypothesis will be concluded. 


\section{INSIGHTS INTO REGIONAL DEVELOPMENT}

ISSN 2669-0195 (online) http://jssidoi.org/IRD/

2020 Volume 2 Number 3 (September)

http://doi.org/10.9770/IRD.2020.2.3(5)

Adeniran (2018) reaffirmed that it is important to be meticulous about the term "reject" and "cannot reject". Even if the Null Hypothesis was decided not to be rejected that does not mean that it will be accepted. A Null Hypothesis is a hypothetical statement that is expected to be disproved therefore it can never be accepted but it might not be rejected. Instead of using the statement "accept the Null Hypothesis" it is best to adopt the statement that "Null Hypothesis cannot be rejected".

The result reveals that strategic management accounting significantly influences the performance of the transport business at a p-value of 0.000 which is less than the critical region at 0.05 . Also, the level of explanation (64.4 percent) is a numerical implication that the performance of the transport business is influenced by strategic management accounting at 64.4 percent. Also, the correlation value of 0.803 implies that the performance of the transport business is positively, and strongly caused by strategic management accounting.

Furthermore, the level of technology involved is significantly influencing the performance of the transport business at a p-value of 0.002 which is less than the critical region at 0.05 . Also, the level of explanation (80.5 percent) is a numerical implication that the performance of the transport business is highly influenced by technology at 80.5 percent. Also, the correlation value of 0.897 implies that the performance of the transport business is positively, and strongly caused by the level of technology expended.

Moreover, the level of information obtained in running the business is significantly influencing the performance of the transport business at a p-value of 0.044 which is less than the critical region at 0.05 . Also, the level of explanation (35.1 percent) is a numerical implication that the performance of the transport business is influenced by the information at 35.1 percent. Also, the correlation value of 0.401 implies that the performance of the transport business is positively caused by the level of information obtained for running the business.

Additionally, the number of people in the business is significantly influencing the performance of the transport business at $a$ p-value of 0.002 which is less than the critical region at 0.05 . Also, the level of explanation (33.3 percent) is a numerical implication that the performance of the transport business is influenced by the number of people at 33.3 percent. Also, the correlation value of 0.364 implies that the performance of the transport business is positively caused by the number of people working in the business enterprise. It is paramount to note that it does not only depend on the number of staff but the knowledge of staff in respective offices.

Finally, on the analysis, the government policy is significantly influencing the performance of the transport business at a p-value of 0.000 which is less than the critical region at 0.05 . Also, the level of explanation (90.8 percent) is a numerical implication that the performance of the transport business is to a greater extent influenced by the government policy at 90.8 percent. Also, the correlation value of 0.953 implies that the performance of the transport business is positively, and strongly caused by government policy (See Table 1). 
INSIGHTS INTO REGIONAL DEVELOPMENT

ISSN 2669-0195 (online) http://jssidoi.org/IRD/ 2020 Volume 2 Number 3 (September) http://doi.org/10.9770/IRD.2020.2.3(5)

Table 1. Summary of regression result

\begin{tabular}{|l|l|l|l|l|}
\hline Performance of Transport Business & $\mathbf{R}$ & $\mathbf{R}^{\mathbf{2}}$ & Sig & Decision \\
\hline 1. Strategic management accounting & 0.803 & 0.644 & $\mathbf{0 . 0 0 0}$ & Sig \\
\hline 2. Technology & 0.897 & 0.805 & $\mathbf{0 . 0 0 2}$ & Sig \\
\hline 3. Information & 0.401 & 0.351 & $\mathbf{0 . 0 4 4}$ & Sig \\
\hline 4. People & 0.364 & 0.333 & $\mathbf{0 . 0 0 2}$ & Sig \\
\hline 5. Government & 0.953 & 0.908 & $\mathbf{0 . 0 0 0}$ & Sig \\
\hline
\end{tabular}

$* \mathrm{P}<0.001, * *<0.05, * * * \mathrm{p}<0.001$, Sig $=$ Significant, NS $=$ Not Significant

Source: SPSS Version 20

\section{Conclusions}

The central aim of this study is to examine the significance of strategic management accounting towards the realization of better performance regarding transport businesses in and Nigeria. Transportation is a derived demand that is mostly demanded to satisfy other purposes. Hence, the businesses centering on transportation are usually essential as it enhances regional complementarity of goods and supply between locations, intervening opportunities, and spatial transferability. Primary data was gathered from different owners, top and middle managers of transport enterprises in Nigeria. The study found that there was significance between the impact of strategic management accounting and technology on the performance of the business in Nigeria. This implies that strategic management accounting has an influence on business performance, and technology has to influence business performance. Also, strategic management accounting is well driven by technology which enhances the efficiency of value creation, competitive intensity, and competitive advantage between competitors.

Furthermore, there was a significant impact between information, people, and governmental policy on business performance in Nigeria. Hence information, people, and government policy should be properly given great attention to realize the significant performance of the transport business in Nigeria. Finally, strategic management accounting is considered to give varying results in a different environment especially the non-crises areas. Hence, there is a need for further studies.

\section{References}

Adeniran, A. O. (2018). Establishing chi-square as a non-parametric test in descriptive statistics. Science and Technology, 4, 106-113

Arowomole, K.A. (2000). Modern Business Management (Theory and Practice). $1^{\text {st }}$ Edition. Sango-Ota, Ogun State: Ade-Oluyinka Commercial Press.

Bryman, A., and Bell, E. (2007). Business Research Methods (2 ${ }^{\text {nd }}$ ed.). New York: Oxford University Press.

Chaffee, E. (1985). Three Models of Strategy. Academy of Management Review, 10(1), 89-98.

Cooper, R. (1996). Costing Techniques to Support Corporate Strategy: Evidence from Japan. Management Accounting Research, 7, 219246.

Dent, J. F. (1990). Strategy, Organization, and Control: Some Possibilities for Accounting Research. Accounting, Organizations, and Society, 15(1-2), 3-25. 


\section{INSIGHTS INTO REGIONAL DEVELOPMENT}

ISSN 2669-0195 (online) http://jssidoi.org/IRD/ 2020 Volume 2 Number 3 (September) http://doi.org/10.9770/IRD.2020.2.3(5)

Economic Commission for Africa, ECA (2001). Enhancing the Competitiveness of Small and Medium Enterprises in Africa: A Strategic Framework for Institutional Support, Addis Ababa: Economic Commission for Africa Publication.

Enterprises Struggle in Iraq: Retrieved on Thursday, 20th February $2020 \quad$ from http://www.internationalbusinessreview.net/SouthAsiaTheMiddleEast/NewsInBrief/tabid/290/vw/1/ItemID/1277/Default.aspx.

France, A. (2006). An Alternative Approach to Surveying Management Accounting Practices. Waikato Institute of Technology (Wintec), New Zealand, 1-20.

Hill, J. (2001). A Multidimensional Study of the Key Determinants of Effective SME Marketing Activity: Part I. International Journal of Entrepreneurial Behaviour and Research, 7(5), 171-204.

Johnson, G. (1987). Strategic Change and the Management Process. Oxford: Blackwell Publishers.

Julie, P. (2007). SPSS Survival Manual: A Step-by-Step Guide to Data Analysis using SPSS for Windows (version 15). (3 ${ }^{\text {rd }}$ ed.). Australia: Allan and Unwin.

Lindblom, C. (1959). The Science of Muddling Through. Public Administration Review, 19, 79-88.

Malhotra, M., Chen, Y., Criscuolo, A., Fan, Q., Hamel, I. I., and Savchenko, Y. (2006). Expanding Access to Finance: Good Practices and Policies for Micro, Small, and Medium Enterprises. Washington. DC: The World Bank Institute.

Miles, R. E., and Snow, C. C. (1978).Organizational Strategy, Structure, and Process. New York: McGraw-Hill.

Minztberg, H., Raisinghani, O., and Theoret, A. (1976).The Structure of Unstructured Decision Process. Administrative Science Quarterly, $21,246-275$

Neely, A. M., and Gregory, K. P. (1995). Performance Measurement System Design: A Literature Review and Research Agenda. International Journal of Operations and Production Management, 15(4) 80-116.

Neil, J. (2009). Exploring Research. $7^{\text {th }}$ Edition. New Jersey: Pearson Education International, Inc.

Norman, B. M., and Paolo, Q. (2010). Management Accounting and Control System: An Organizational and Sociological Approach.

OECD (2004). Effective Policies for Small Business: A Guide for the Policy Review Process and Strategic Plans for Micro, Small, and Medium Enterprise Development. Paris: Publication of the Organization for Economic Cooperation and Development.

Okpara, J. O., and Wynn, P. (2007). Determinants of Small Business Growth Constraints in a Sub-Saharan African Economy. SAM Advanced Management Journal, 72(2), 24-35.

Othman, R. (2005). A Comprehensive Analysis of Electronic Government Blueprint for Implementation towards the Actual E-government Implementation. MSc (IT) thesis, Universiti Utara Malaysia.

Otley, D. (2001). Extending the Boundaries of Management Accounting Research: Developing Systems for Performance Management. British Accounting Review, 33, 243-261.

Quinn, J. (1980). Strategies for Change: Logical Incrementalism. Homewood Ill: Richard Irwin.

Roslender, R., and Hart, S. J., (2002). Integrating Management Accounting and Marketing in the Pursuit of Competitive Advantage: The Case for SMA. Critical Perspectives on Accounting, 13, 255-277.

Ruth, J-PS. (2000). So Far Small Biz is only Dabbling in E-Commerce. Business News, 13(23), New Jersey.

Santala, R. (1996). Post-Acquisition Integration of Strategic Management in an MNC. Publications of the Turku School of Economics and Business Administration, Series A-2:1996. 


\section{INSIGHTS INTO REGIONAL DEVELOPMENT}

ISSN 2669-0195 (online) http://jssidoi.org/IRD/ 2020 Volume 2 Number 3 (September) http://doi.org/10.9770/IRD.2020.2.3(5)

Sekaran, U., Robert, Y. C., and Brain, L. D. (2001). Applied Business Research (1 ${ }^{\text {st }}$ ed.). Australia: John Wiley and Sons Australian Ltd.

Senan, N.A.M. (2018). Developmental review program impact on enhancing the effectiveness of "Teaching and Learning" in accounting program: a case study in a Saudi University. Entrepreneurship and Sustainability Issues, 6(2), 1001-1017. http://doi.org/10.9770/jesi.2018.6.2(35)

Shehab, M. A. (2008). Factors Influencing Accounting Information System Performance among Small and Medium Enterprises (SMEs) in Tripoli. MSc Theses, Universiti Utara Malaysia.

Simons, R. (2000). Performance Measurement and Control Systems for Implementing Strategy, Text, and Cases. Prentice-Hall, Upper Saddle River, NJ.

Soleman, A. M. (2008). Factors Influencing the Adoption of Web-Based Information System: A Case Study at Lada in Langkawi, Kedah. MSc Thesis, Universiti Utara Malaysia.

Trkman, P. (2009). The Critical Success Factors of Business Process Management. International Journal of Information Management, 30(2), 125-134. https://doi.org/10.1016/j.ijinfomgt.2009.07.003

Uyar, A. (2010). Cost and management accounting practices: A Survey of Manufacturing Companies. Eurasian Journal of Business and Economics, 3(6), 113-125.

Vegera, S., Malei, A., Sapeha, I. and Sushko, V. (2018). Information support of the circular economy: the objects of accounting at recycling technological cycle stages of industrial waste. Entrepreneurship and Sustainability Issues, 6(1), 190-210. $\underline{\text { http://doi.org/10.9770/jesi.2018.6.1(13) }}$

Wakuła, M. (2020). The importance of accounting and reporting in the process of finance management in a basic unit of the territorial government. Entrepreneurship and Sustainability Issues, 7(3), 1996-2011. https://doi.org/10.9770/jesi.2020.7.3(37)

Zikmund, W.G. (2003). Business Research Methods (7th ed.). South-Western.

\section{Contributions of Authors}

\begin{tabular}{|l|l|l|}
\hline Name of the Author(s) & $\begin{array}{l}\text { Contribution of } \\
\text { authors }(\%)\end{array}$ & $\begin{array}{l}\text { Description of the contribution of authors (concepts, } \\
\text { design, analysis, and interpretation of data, methods, } \\
\text { etc. ) }\end{array}$ \\
\hline Adetayo Olaniyi ADENIRAN & 60 & Design, Methodology, and final edited \\
\hline Oluwabukunmi Eunice OBEMBE & 40 & Design, Literature, and Methodology \\
\hline
\end{tabular}


INSIGHTS INTO REGIONAL DEVELOPMENT

ISSN 2669-0195 (online) http://jssidoi.org/IRD/ 2020 Volume 2 Number 3 (September)

http://doi.org/10.9770/IRD.2020.2.3(5)

Adetayo Olaniyi ADENIRAN is a Doctoral student in the Department of Transport Technology, Federal University of Technology, Akure. He is the founder of the Buty Global research network.

ORCID ID: orcid.org/0000-0002-6870-1212

Oluwabukunmi Eunice OBEMBE is a graduate of Accounting in the Department of Accounting, Faculty of Management Science, National Open University of Nigeria. She is currently a lead researcher in Buty Global research network (www.butyglobal.com)

ORCID ID: orcid.org/0000-0002-3529-0648

Make your research more visible, join the Twitter account of INSIGHTS INTO REGIONAL DEVELOPMENT:

@IntoInsights

Copyright (C) 2020 by author(s) and VsI Entrepreneurship and Sustainability Center

This work is licensed under the Creative Commons Attribution International License (CC BY).

http://creativecommons.org/licenses/by/4.0/

(c) (i) Open Access 